\title{
NEED ASSESSMENT METODE PEMBELAJARAN PADA PERKULIAHAN STATISTIK PENELITIAN PENDIDIKAN DIMASA COVID-19
}

Rendy Wikrama Wardana dan Afrizal Mayub

Pendidikan IPA, Universitas Bengkulu, Bengkulu, Indonesia

Corresponding author email: rendywardana@unib.ac.id

\section{Info Artikel}

Diterima:

05 November 2020

Disetujui:

17 Juni 2021

Dipublikasikan:

30 Juni 2021

\begin{abstract}
Abstrak:
Penelitian bertujuan untuk menggambarkan kebutuhan akan metode pembelajaran yang tepat pada perkuliahan statistik penelitian pendidikan dimasa covid-19. Jenis penelitian yang digunakan adalah deskriptif kuantitatif. Sampel penelitian berjumlah 59 mahasiswa yang terdiri dari 20 mahasiswa S2 pendidikan IPA dan 39 mahasiswa S1 pendidikan Fisika disalah satu Universitas Negeri Di Kota Bengkulu. Instrumen penelitian berupa angket respons mahasiswa yang terdiri dari 8 item pertanyaan. Pengumpulan data dilakukan melalui penyebaran angket melalui google form. Analisis data dilakukan dengan statistik deskriptif. Hasil penelitian memperlihatkan bahwa metode pembelajaran Scafolding menjadi salah satu alternatif metode pembelajaran dimasa covid 19. Selain itu, perkuliahan statistik penelitian pendidikan memiliki karakteristik sulit dan kompleks terutama dalam proses analisis data.
\end{abstract}

Kata Kunci: Need assesment, metode, pembelajaran, statistik, covid-19

\begin{abstract}
:
The study aims to describe the need for appropriate learning methods in educational research statistics lectures in the Covid-19 era. The type of research used was descriptive quantitative. The research sample amounted to 59 students consisting of 20 students from the master's degree program in science education and 39 students from the bachelor's program in physics education at one of the State Universities in Bengkulu City. The research instrument was a student response questionnaire consisting of 8 question items. Data collection was done through the distribution of questionnaires via google form. Data analysis was performed with descriptive statistics. The results of the study show that the Scafolding learning method is an alternative learning method in the era of covid 19. In addition, educational research statistics lectures have difficult and complex characteristics, especially in the data analysis process.
\end{abstract}

Keywords: Need assessment, methods, learning, statistics, covid-19 


\section{Pendahuluan}

Wabah pendemi Corona atau yang lebih dikenal dengan Covid 19 menjadi salah satu penyakit yang sangat berdampak bagi negara Indonesia baik dari segi kesehatan, ekonomi maupun pendidikan. Pada aspek pendidikan beberapa program pemerintah di bidang pendidikan menjadi terbengkalai dan tidak dapat berjalan dengan maksimal. Sebagai contoh Sekolah-sekolah dan perguruan tinggi tidak dapat menjalankan pembelajaran di kelas karena mewajibkan seluruh peserta didik belajar dari rumah. Hal tersebut diperkuat oleh surat edaran kementerian pendidikan dan kebudayaan Nomor 4 tahun 2020 tentang pelaksanaan kebijakan pendidikan dalam masa darurat penyebarab Corona Virus Disease (COVID-19). Surat edaran tersebut mengatur ketentuan proses Belajar dari Rumah melalui pembelajaran daring/jarak jauh dilaksanakan untuk memberikan pengalaman belajar yang bermakna bagi siswa, tanpa terbebani tuntutan menuntaskan seluruh capaian kurikulum untuk kenaikan kelas maupun keluiusan.

Kegiatan proses Belajar dari Rumah dapat difokuskan pada pendidikan kecakapan hidup serta Aktivitas dan tugas pembelajaran Belajar dari Rumah dapat bervariasi antarsiswa, sesuai minat dan kondisi masing-masing, termasuk mempertimbangkan kesenjangan akses/ fasilitas belajar di rumah. Beberapa permasalahan timbul bahwa pembelajaran menjadi kurang efektif karena peserta didik belajar secara mandiri dengan segala keterbatasan yang ada. Berdasarkan studi lapangan yang dilakukan pada mahasiswa semester empat di salah satu prodi Magister di kota bengkulu mengungkapkan bahwa terdapat beberapa mata kuliah yang sulit dipahami dan kurang optimal apabila belajar secara online dan mandiri. Salah satu mata kuliah tersebut adalah mata kuliah statistika penelitian pendidikan sains. Mata kuliah statistik menjadi dasar dan pedoman dalam teknik pengolahan data tugas akhir mahasiswa (Tesis). Mahasiswa cenderung langsung mengolah data menggunakan sistem yang hasil datanya langsung keluar tanpa dipahami bagaimana proses pengolahan data itu terjadi, serta kurang teliti dalam penggunaan statistik dalam tugas akhir.

Pembelajaran akan menjadi maksimal apabila didukung oleh desain pembelajaran yang tersusun, sistematis dan dapat memberikan akses materi yang mudah dipahami peserta didik. Oleh sebab itu perlu dikaji karakteristik konten statistik penelitian pendidikan dan metode pembelajaran yang tepat dimasa covid 19 melalui studi analisis kebutuhan.

\section{Metode Penelitian}

Jenis penelitian ini adalah deskriptif kuantitatif (Creswel, 2012). Penelitian ini dilaksanakan pada bulan September-Oktober 2020 di salah satu Universitas Negeri di Kota Bengkulu. Sampel penelitian berjumlah 59 mahasiswa yang terdiri dari 20 mahasiswa s2 pendidikan IPA dan 39 mahasiswa S1 pendidikan Fisika disalah satu universitas negeri di kota Bengkulu yang telah mengikuti perkuliahan statistik penelitian pendidikan pada tingkat maupun semester sebelumnya. Instrumen penelitian berupa angket respons mahasiswa yang terdiri dari 8 item pertanyaan mengenai Pengetahuan dan karakteristik perkuliahan statistik penelitian pendidikan, serta karakteristik metode pembelajaran yang tepat dimasa covid-19. Proses pengumpulan data dilakukan dengan menyebarkan angket respons mahasiswa melalui google form yang kemudian dianalisis secara deskriptif.

\section{Hasil Penelitian dan Pembahasan}

Penelitian dilaksanakan bulan september sampai dengan awal oktober tahun 2020 melalui penyebaran angket melalui google form. Angket terdiri atas 8 item pertanyaan terbuka yang menggambarkan karakteristik materi dan metode pembelajaran dalam perkuliahan statistik penelitian pendidikan. Gambaran hasil penelitian dideskripsikan sebagai berikut :

\section{Pemahaman Terhadap Perkuliahan Statistik Penelitian Pendidikan}

Item pertanyaan pertama menggambarkan bagaimana pemahaman mahasiswa terkait perkuliahan statistik penelitian pendidikan. Pemahaman mahasiswa pada perkuliahan statistika penelitian pendidikan yang direpresentasikan pada Gambar 1. 


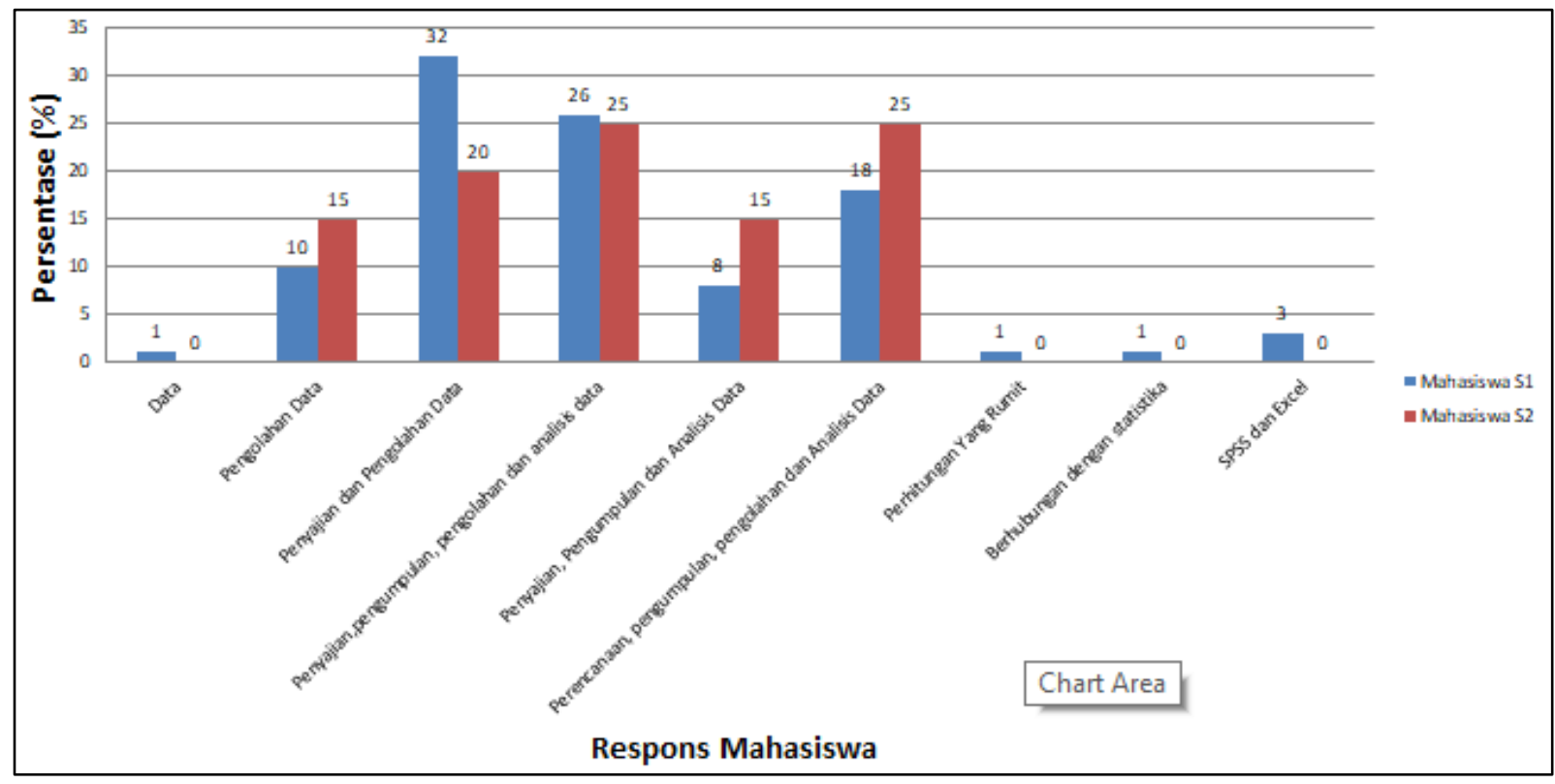

Gambar 1. Respons mahasiswa pada item pertanyaan ke-1

Berdasarkan Gambar 1 di atas, terdapat sembilan respons mahasiswa terkait pemahaman pada perkuliahan statistika penelitian pendidikan sains diantaranya : 1) data, 2) Pengolahan data, 3) Penyajian dan pengolahan data, 4) Penyajian, pengumpulan, pengolahan dan analisis data, 5) Penyajian, pengumpulan dan analisis data, 6) perencanaan, pengumpulan, pengolahan dan analisis data, 7) perhitungan yang rumit, 8) berhubungan dengan statistika dan 9) berkaitan dengan SPSS dan Excell. Sebagian besar memperlihatkan bahwa $32 \%$ mahasiswa S1 memahami perkuliahan statistika penelitian pendidikan sebagai matakuliah yang berkaitan dan pengolahan dan penyajian data. Pada mahasiswa S2 terdapat masing masing $25 \%$ mengungkapkan bahwa mata kuliah statistika berkaitan dengan perencanaan, pengumpulan, pengolahan dan analisis data. Hasil tersebut relevan dengan ungkapan Creswell (2012) yang menyebutkan bahwa statistik penelitian berkaitan dengan perencanaan, pengumpulan, pengolahan dan analisis data baik kualitatif maupun kuantitatif.

\section{Sikap Terhadap Perkuliahan Statistik Penelitian Pendidikan}

Item pertanyaan kedua menggambarkan bagaimana sikap mahasiswa terhadap perkuliahan statistik penelitian pendidikan. sikap mahasiswa pada perkuliahan statistika penelitian pendidikan yang direpresentasikan pada Gambar 2.

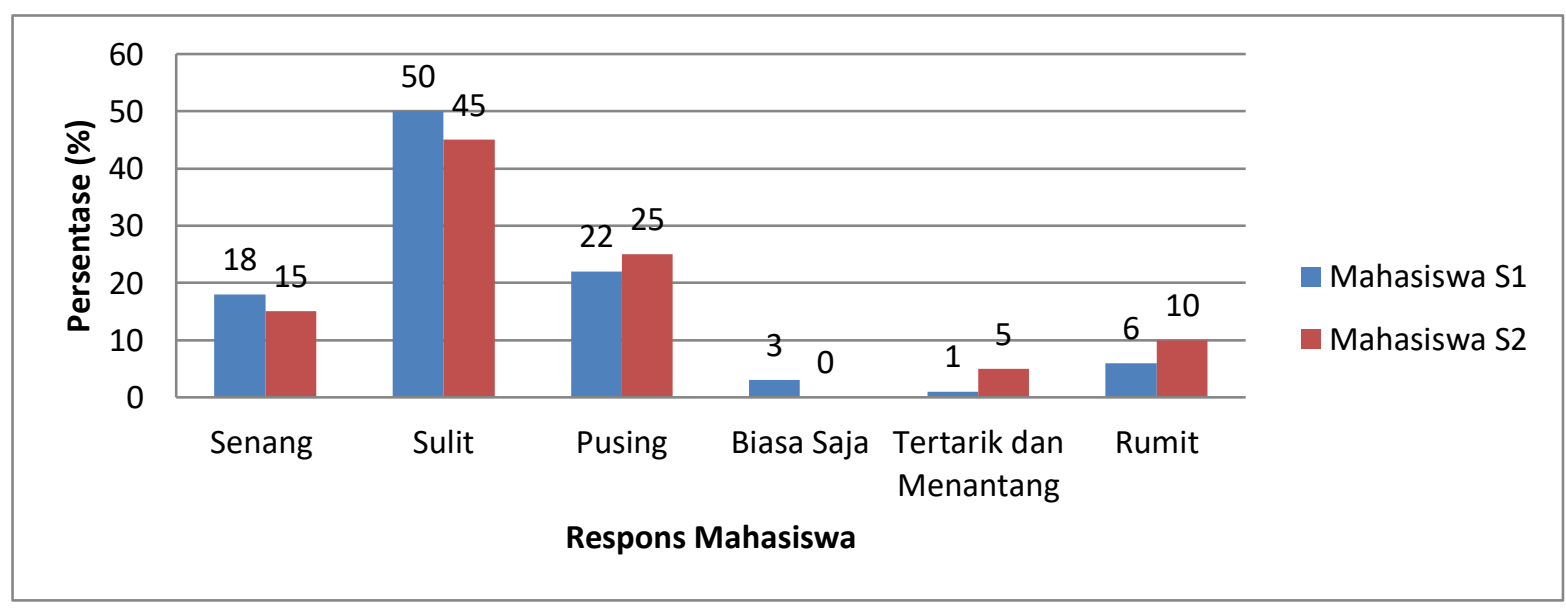

Gambar 2. Respons mahasiswa pada item pertanyaan ke-2 
Berdasarkan Gambar 2 di atas, terdapat enam respons mahasiswa terkait sikap pada perkuliahan statistika penelitian pendidikan sains diantaranya : 1) senang 2) sulit, 3) pusing, 4) biasa saja, 5) tertarik dan menantang, dan 6) rumit. Sebagian besar memperlihatkan bahwa $50 \%$ mahasiswa S1 dan $45 \%$ mahasiswa S2 merasa sulit untuk belajar statistika. Hasil penelitian diperkuat oleh pernyataan Papanastasiou (2005) yang mengungkapkan bahwa Sikap negatif yang ditunjukan dari sulitnya belajar statistika disebabkan oleh penggunaan metode pembelajaran yang tidak tepat.

3. Karakteristik Materi Perkuliahan Statistik Penelitian Pendidikan

Item pertanyaan ketiga menggambarkan bagaimana karakteristik perkuliahan statistik penelitian pendidikan. Karakteristik perkuliahan statistika penelitian pendidikan yang direpresentasikan pada Gambar 3.

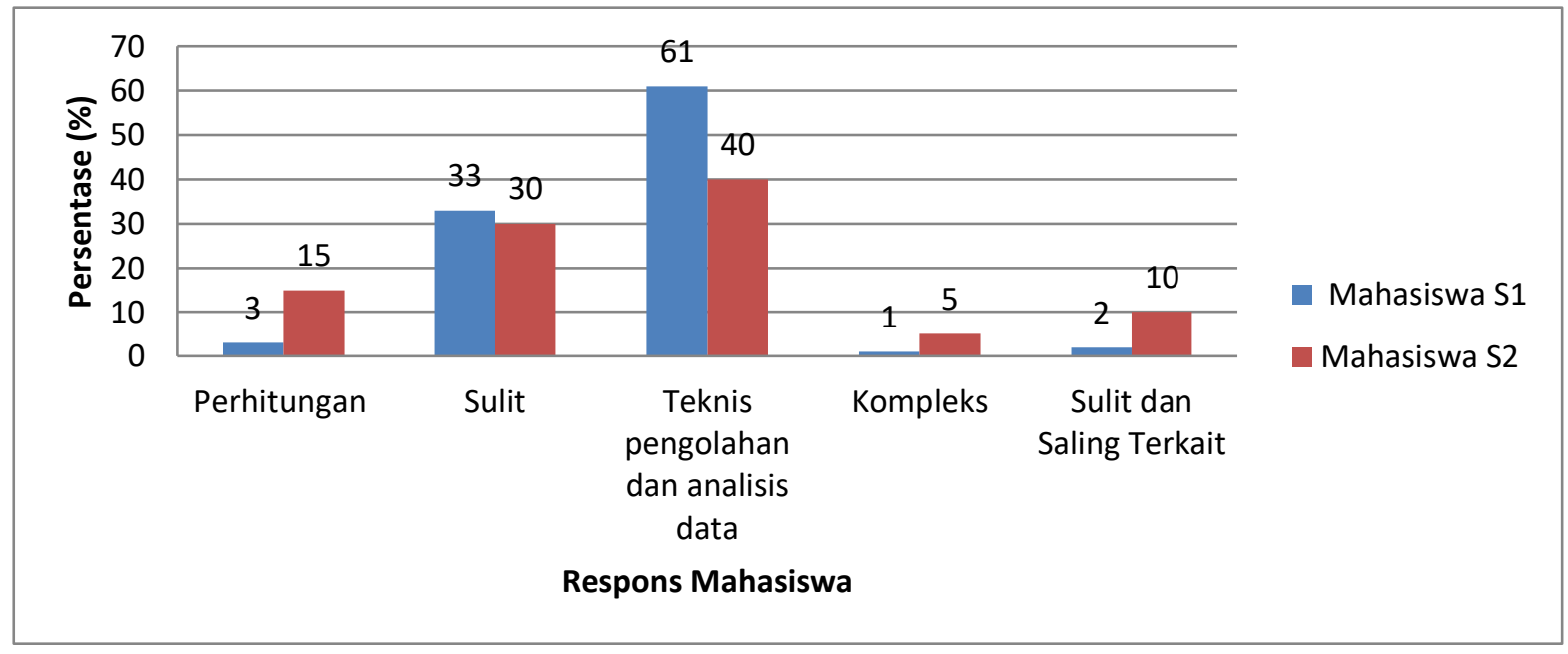

Gambar 3. Respons mahasiswa pada item pertanyaan ke-3

Berdasarkan Gambar 3 di atas, terdapat lima respons mahasiswa terkait karakteristik perkuliahan statistika penelitian pendidikan sains diantaranya : 1) perhitungan 2) sulit 3) Teknis pengolahan dan analisis data, 4) kompleks, dan 5) sulit dan saling terkait. Sebagian besar memperlihatkan bahwa $61 \%$ mahasiswa S1 dan $40 \%$ mahasiswa S2 mengungkapkan bahwa karakteristik perkuliahan statistik berkaitan dengan teknis pengolahan dan analisis data. Hasil penelitian diperkuat oleh pernyataan Dewi dan Afrizon (2018) yang mengungkapkan bahwa memiliki karakteristik yang kompleks berkaitan dengan pengolahan dan analisis data .

4. Konten Perkuliahan Statistik Penelitian Pendidikan yang Mudah Dipahami

Item pertanyaan keempat menggambarkan bagaimana konten perkuliahan statistik penelitian pendidikan yang mudah dipahami. Konten perkuliahan statistika penelitian pendidikan yang mudah dipahami mahasiswa direpresentasikan pada Gambar 4 


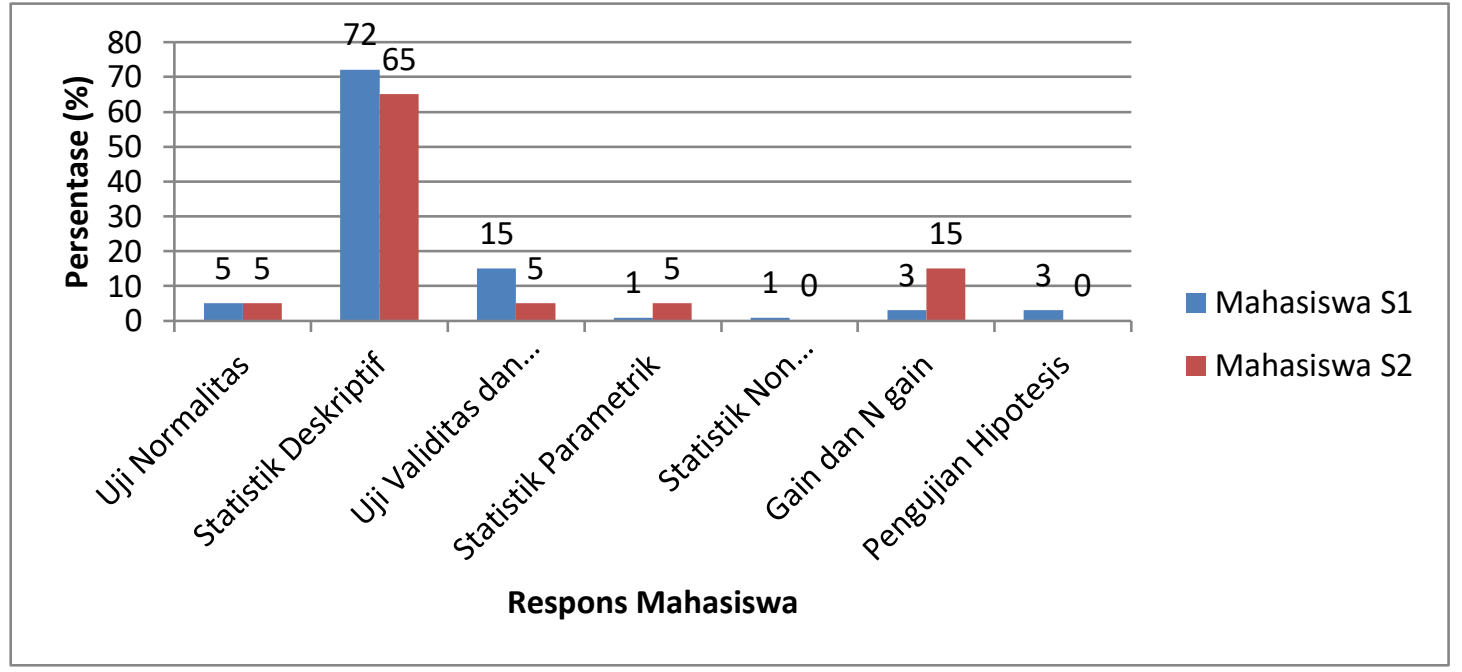

Gambar 4. Respons mahasiswa pada item pertanyaan ke-4

\section{Konten Perkuliahan Statistik Penelitian Pendidikan yang Sulit Dipahami}

Item pertanyaan kelima menggambarkan bagaimana konten perkuliahan statistik penelitian pendidikan yang sulit dipahami. Konten perkuliahan statistika penelitian pendidikan yang sulit dipahami mahasiswa direpresentasikan pada Gambar 5.

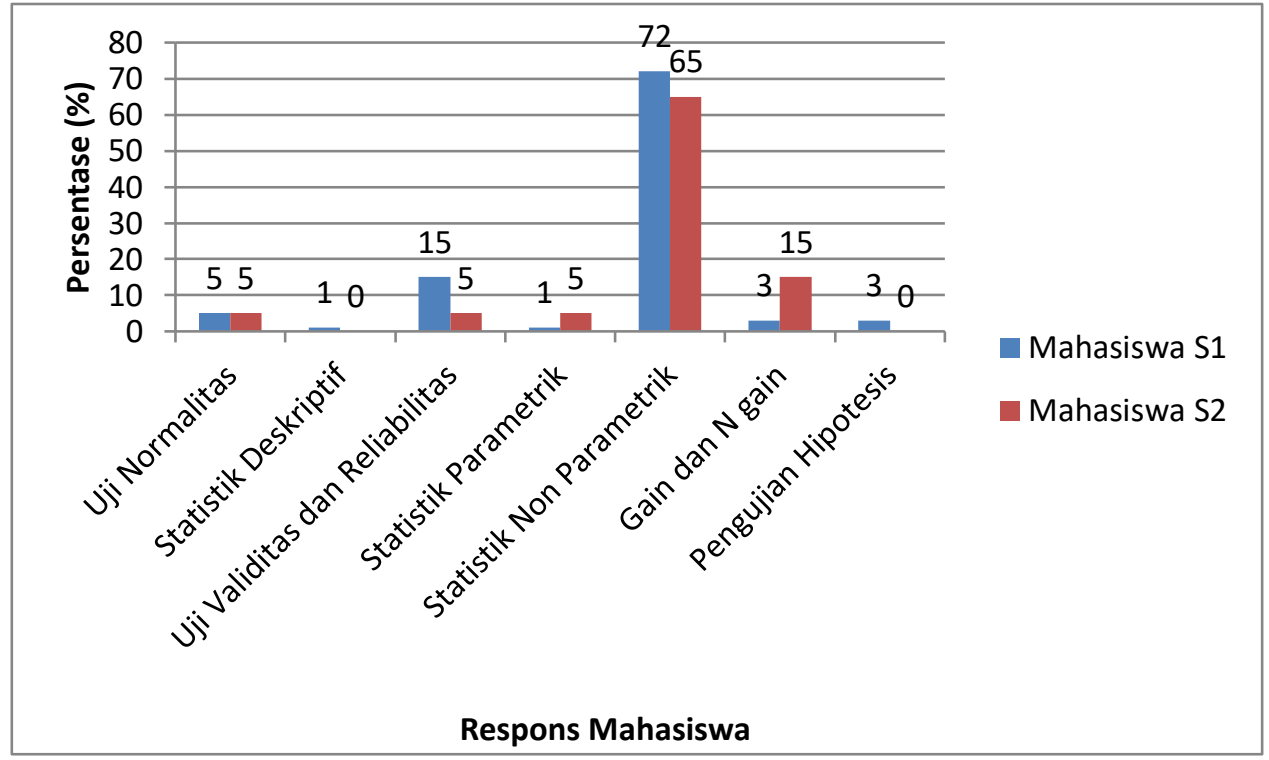

Gambar 5. Respons mahasiswa pada item pertanyaan ke-5

Berdasarkan Gambar 5 di atas, terdapat tujuh respon mahasiswa terkait konten perkuliahan statistika penelitian pendidikan sains yang sulit dipahami diantaranya : 1) Uji Normalitas 2) Statistik Deskriptif 3) Uji Validitas dan Reliabilitas, 4) statistik parametrik, 5) Statistik Non parametrik, 6) Gain dan Ngain, dan 7) pengujian hipotesis. Sebagian besar memperlihatkan bahwa $72 \%$ mahasiswa S1 dan $65 \%$ mahasiswa S2 mengungkapkan bahwa materi statistik non parametrik merupakan materi yang sulit dipahami. Hal tersebut dikarenakan statistik non parametrik berkenaan dengan data yang tidak terdistribusi normal dan bersifat flesibel (Santoso, 2010). 
6. Dampak Perkuliahan Statistik Penelitian Pendidikan dalam Tugas Akhir

Item pertanyaan keenam menggambarkan dampak perkuliahan statistik penelitian pendidikan dalam tugas akhir. Dampak perkuliahan statistika penelitian pendidikan dalam tugas akhir mahasiswa direpresentasikan pada Gambar 6.

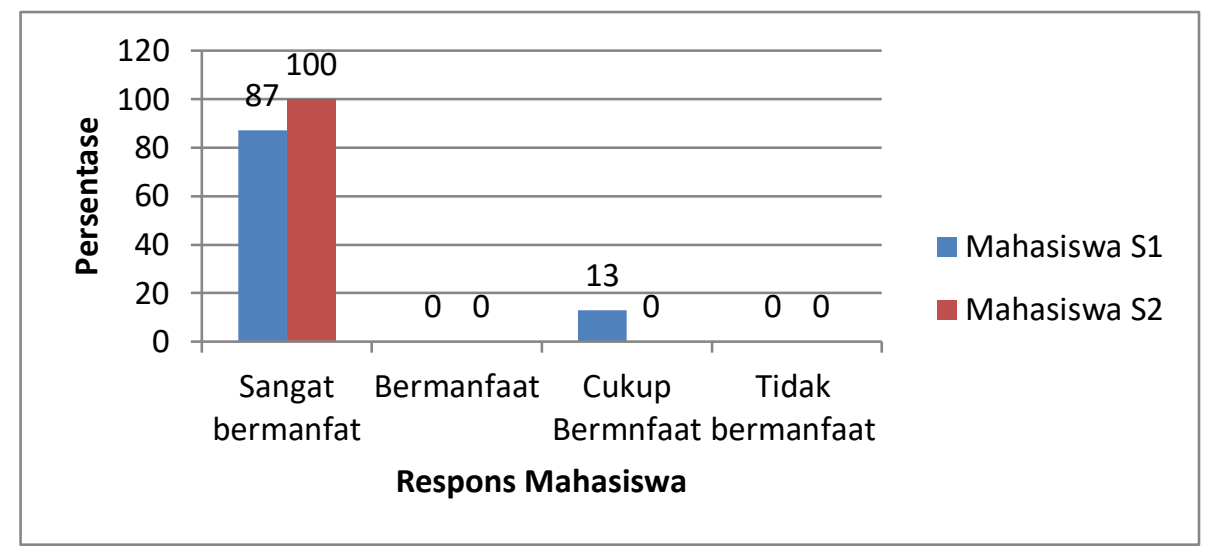

Gambar 6. Respon mahasiswa pada item pertanyaan ke-6

Berdasarkan Gambar 6 di atas, terdapat empat respon mahasiswa terkait dampak perkuliahan statistika penelitian pendidikan sains dalam tugas akhir diantaranya : 1) sangat bermanfaat 2) bermanfaat, 3) cukup bermanfaat dan, 4) tidak bermanfaat. Mayoritas memperlihatkan bahwa $87 \%$ mahasiswa S1 dan $100 \%$ mahasiswa S2 mengungkapkan bahwa perkuliahan statistik sangat bermanfaat dalam menunjang tugas akhir. Hal tersebut diperkuat dengan pernyataan Taplin (2007) mengungkapkan bahwa matematika dalam hal ini statistik dapat membantu permasalahan sehari-hari yang berkenaan dengan pengolahan dan analisis data.

7. Metode Pembelajaran yang digunakan Dosen pada perkuliahan Statistik Penelitian Pendidikan

Item pertanyaan ketujuh menggambarkan Metode Pembelajaran yang digunakan Dosen pada perkuliahan statistik penelitian pendidikan. Metode Pembelajaran yang digunakan Dosen pada perkuliahan statistika penelitian pendidikan direpresentasikan pada Gambar 7.

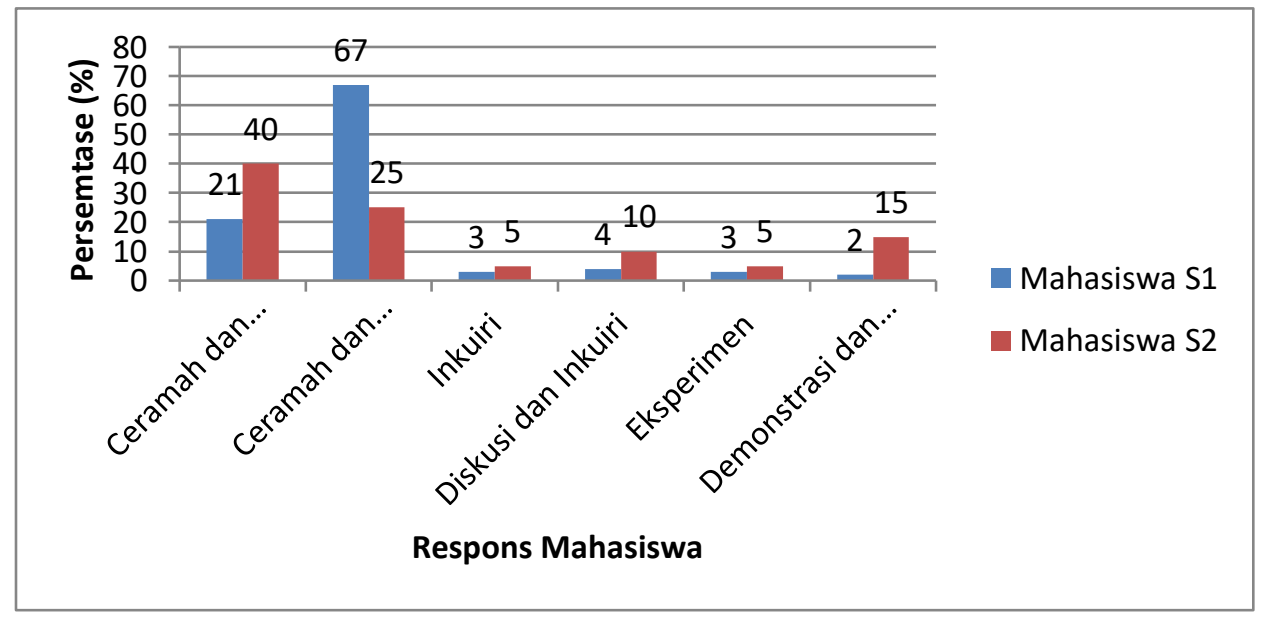

Gambar 7. Respons mahasiswa pada item pembelajaran ke-7

Berdasarkan Gambar 7 di atas, terdapat enam respon mahasiswa terkait metode pembelajaran yang 
digunakan dosen pada perkuliahan statistika penelitian pendidikan diantaranya : 1) ceramah dan tanya jawab, 2) ceramah dan diskusi, 3) inkuiri, 4) Diskusi dan inkuiri, 5) Eksperimen dan, 6) demonstrasi dan simulasi. Sebagian besar memperlihatkan bahwa $67 \%$ mahasiswa S1 dan $25 \%$ mahasiswa S2 mengungkapkan bahwa metode ceramah dan diskusi merupakan metode pembelajaran yang sering dilakukan dosen pada perkuliahan statistika penelitian pendidikan. Hasil tersebut diperkuat dengan pernyataan Sagala (2009) mengungkapkan bahwa metode ceramah dan diskusi menjadi metode pembelajaran yang umum digunakan pendidik dalam proses pembelajaran.

8. Saran terkait Metode Pembelajaran yang Tepat untuk Perkuliahan Statistik Penelitian Pendidikan dimasa Covid 19

Item pertanyaan kedelapan menggambarkan Metode Pembelajaran yang tepat untuk perkuliahan statistik penelitian pendidikan dimasa covid-19. Metode Pembelajaran yang tepat digunakan Dosen pada perkuliahan statistika penelitian pendidikan dimasa covid-19 direpresentasikan pada Gambar 8.

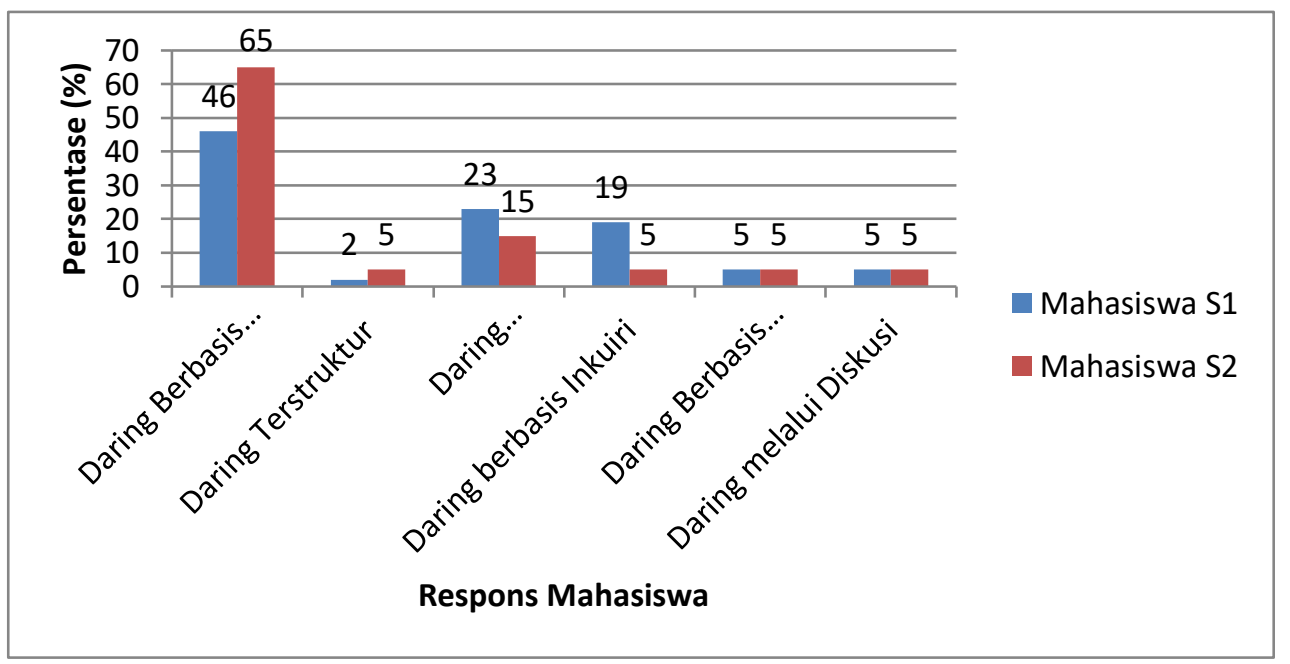

Gambar 8. Respons mahasiswa pada item pertanyaan ke-8

Berdasarkan Gambar 8 di atas, terdapat enam respon mahasiswa terkait metode pembelajaran yang tepat digunakan dosen pada perkuliahan statistika penelitian pendidikan dimasa covid-19 diantaranya : 1) daring berbasis simulasi, 2) daring terstruktur, 3) daring menggunakan aplikasi, 4) daring berbasis inkuiri, 5) daring berbasis eksperimen dan, 6) daring melalui diskusi. Sebagian besar memperlihatkan bahwa $46 \%$ mahasiswa S1 dan $65 \%$ mahasiswa S2 mengungkapkan bahwa metode daring dan simulasi merupakan metode pembelajaran yang tepat pada perkuliahan statistika penelitian pendidikan dimasa covid-19. Merujuk pada hasil dari enam respons mahasiswa memperlihatkan bahwa pola daring menjadi salah satu alternatif utama proses pembelajaran dimasa covid 19. Rangkaian kegiatan merujuk pada salah satu metode pembelajaran yaitu metode pembelajaran Scafolding. Menurut Vigotsky (dalam Trianto, 2010) scaffolding merupakan suatu proses pembelajaran yang terjadi pada anak ketika belajar menyelesaikan tugas-tugas yang belum dipelajari dan berada dalam jangkauan kemampuannya. Siswa akan kesulitan apabila menemukan suatu persoalan baru yang tidak dalam jangkauan kemampuan siswa dalam mempelajari suatu konsep. Landasan atau dasar dari metode scaffolding adalah teori konstruktivisme (Sudarman \& Linuhung, 2017). Hal ini berarti bahwa dalam proses pembelajaran siswa mengkonstruksi pengetahuan yang diperoleh secara mandiri (Rahayu et al., 2020) dalam hal ini melalui pembelajaran daring. Pembelajaran scaffolding dapat dimaknai suatu cara pemberian dukungan belajar secara mandiri, terstruktur dari tahapan awal hingga tahap akhir (Suroto et al., 2019). Pemberian dukungan dilakukan secara terus menerus baik berupa dukungan pemberian konsep maupun memberikan gangguan konsep yang menyebabkan siswa dapat merubah konsep yang ada pada dirinya (Albali, 2006). Berdasarkan beberapa pernyataan tersebut dapat ditarik kesimpulan bahwa metode pembelajaran scafolding dapat menjadi salah satu alternatif pembelajaran dimasa covid-19. 


\section{Simpulan}

Metode pembelajaran Scafolding menjadi salah satu alternatif metode pembelajaran dimasa covid 19 dikarenakan dalam proses pembelajaran siswa dapat mengkonstruksi pengetahuan yang diperoleh secara mandiri melalui pembelajaran daring. Metode pembelajaran scafolding memiliki urutan yang terstruktur dan sistematis dari awal kegiatan hingga akhir kegiatan yang dapat membantu siswa dalam mengkonstruk pengetahuannya. Pada aspek konten perkuliahan statistik penelitian pendidikan digambarkan memiliki karakteristik sulit dan kompleks dalam proses pengolahan data.

\section{Referensi}

Creswell, J.W. (2012). Educational Reasearch: Planning, Conducting, and Evaluting Quantitative and Qualitive Research 4th Edition. Boston: Pearson

Dewi, W.S \& Afrizon. R. (2018). Analisis Kondisi awal perkuliahan mahasiswa pendidikan fisika dalam rangka mengambangkan bahan ajar statistika pendidikan fisika menggunakan model problem solving. Jurnal Eksakta Pendidikan, 2(1).

Ghozali, I. (2011). Aplikasi Analisis Multivariate Dengan Program SPSS. Semarang: Badan Penerbit Universitas Diponegoro.

Papanastasiou, E. C. (2005). Factor Structure of The Attitudes toward Research Scale. Statistics Education Research Journal, Vol. 4.

Rahayu, P., Warli, W., \& Cintamulya, I. (2020). Scaffolding Dalam Pembelajaran Mata Kuliah Struktur Aljabar. JIPMat, 5(1). https://doi.org/10.26877/jipmat.v5i1.4838

Sagala, S. (2009). Konsep dan makna pembelajaran untuk memecahkan problematika belajar dan mengajar. Bandung : Alfabeta.

Santoso, S. (2010). Statistik Non Parametrik Konsep dan aplikasinya dengan SPSS. Jakarta : Elexmedia Komputindo.

Sudarman, S. W., \& Linuhung, N. (2017). Pengaruh Pembelajaran Scafolding Terhadap Pemahaman Konsep Integral Mahasiswa. AKSIOMA: Jurnal Program Studi Pendidikan Matematika, 6(1), 33. https://doi.org/10.24127/ajpm.v6i1.866

Suroto, S., Rusman, T., \& Aswir, E. S. (2019). Perbandingan Model Pembelajaran Scafolding Dan Artikulasi Terhadap Kecakapan Hidup Dengan Memperhatikan Emotional Question Siswa. Jurnal Perspektif Pendidikan, 13(2), 83-91. https://doi.org/10.31540/jpp.v13i2.638

Taplin, M. (2007). Mathematics through Problem solving. http//mathgoodies.com/articles/ diakses oktober 2020. 